Menna, M. E. DI (1955). J. gen. Microbiol. 12, 54-62.

\title{
A Search for Pathogenic Species of Yeasts in New Zealand Soils
}

\author{
By MARGARET E. DI MENNA \\ Department of Microbiology, University of Otago, Dunedin, New Zealand
}

SUMMARY: One hundred soils from various parts of the South Island of New Zealand were cultivated on an acid medium at $37^{\circ}$. Stockyard soils yielded most yeasts by this treatment, principally strains of Rhodotorula mucilaginosa and Candida parapsilosis. Few yeasts were isolated from rural soils, and very few from urban soils. Candida albicans was recovered from two soils, one from an urban area and one from a stockyard. Cryptococcus neoformans was not isolated.

The yeast flora which grew at room temperature $\left(c .18^{\circ}\right)$ of 8 soils was also examined. One of these, a peat soil, yielded a pure culture of Candida brumptii. Species of Cryptococcus and Trichosporon were dominant in the other seven samples, and their yeast population as a whole was of colourless, capsulated, non-fermenting, starch synthesizing and nitrate utilizing organisms.

Some years ago an experiment was carried out in this laboratory on the ability of the pathogenic yeasts Cryptococcus neoformans (Sanfelice) Vuillemin and Candida albicans (Robin) Berkhout to survive in soil. Suspensions of cultures which had been recovered from local cases of cryptococcal meningitis and oral thrush were poured over small turf plots which were exposed to the weather. At intervals samples of soil from the plots were cultured on Sabouraud agar of $\mathrm{pH} 4$ and incubated at $37^{\circ}$, conditions which discouraged growth of most members of the normal soil microflora. The pathogens were recoverable for a period of 9 months, at the end of which time it was necessary to destroy the plots. Since then, Emmons (1951) isolated from North American soils four strains of a Cryptococcus species pathogenic for mice, which was almost certainly C. neoformans, although Lodder \& van Rij (1952, p. 375) considered the taxonomic evidence given not sufficiently complete to establish its identity. It did not therefore seem unreasonable to suppose that this pathogen might occur in New Zealand soils, particularly as within the past 5 years four cases of cryptococcal meningitis have been diagnosed here, all in individuals who had spent all their lives within this country.

Candida albicans has been previously reported from a situation unassociated with the mammalian or avian body in one instance, and that not thoroughly authenticated. Negroni \& Fischer (1941) isolated Candida aldoi (Pereira Filho) Cast. \& Jacono from rotting vegetation, and subsequently $C$. aldoi has been placed in synonymy with $C$. albicans. Nevertheless, considering the $50 \%$ incidence of $C$. albicans in the human alimentary tract (Marples \& di Menna, 1952), and its ability to survive for long periods in the soil, it again seems not unlikely that it should be recoverable from that situation.

The present paper records a search for pathogenic yeasts in 100 soil samples. The culture method described above was used so that only yeasts which would grow at $37^{\circ}$ had to be handled. However, a series of eight of the samples were 
also cultured at room temperature $\left(c .18^{\circ}\right)$ and twenty-four yeasts per sample were identified. This was done as a control measure upon the differential culture method used for the entire group. In the sequel the flora which grew at room temperature is referred to as the $18^{\circ}$ flora.

\section{MATERIALS AND METHODS}

The first eighty soil samples were collected at random from various parts of the South Island of New Zealand. It then appeared that most yeasts were recoverable from stockyard soils, so that the last twenty specimens were gathered from a large stockyard at Invermay Research Station, Mosgiel, Otago. Thirty-eight samples were collected from urban areas, thirty-two from rural areas, and thirty from stockyards.

Four of the eight samples of which both the flora which grew at room temperature and the $37^{\circ}$ flora were examined were of tilled soils $(a, b, c, d)$ and four of untilled $(e, f, g, h)$. Soils $(a),(b),(e)$ and $(f)$ were from urban districts, the remainder from the country. The $\mathrm{pH}$ values of these samples were as follows: (a) $\mathrm{pH} \pm 6 \cdot 0,(b) \mathrm{pH} \mathrm{6 \cdot 0-6 \cdot 5,(c)} \mathrm{pH} 6 \cdot 5-7 \cdot 0,(d) \mathrm{pH} \mathrm{6 \cdot 5-7 \cdot 0,}(e) \mathrm{pH}$ $\mathbf{5} \cdot \mathbf{0}-\mathbf{5} \cdot \mathbf{5},(f) \mathrm{pH} \mathbf{5} \cdot \mathbf{0}-\mathbf{5} \cdot \mathbf{5},(g) \mathrm{pH} \pm \mathbf{4} \cdot \mathbf{5},(h) \mathrm{pH} \pm \mathbf{5} \cdot \mathbf{0}$.

Samples were taken from the top inch of soil, care being taken to avoid including any vegetation. Usually the soil was scooped directly by and into a sterile jar, but in a few cases turves were brought directly into the laboratory for sampling there. In the latter case, the outer layer of soil was scraped away before the final sample was taken in order to avoid excessive contamination. Approximately $1 \mathrm{~g}$. soil with as few rootlets as possible was suspended and well shaken in $10 \mathrm{ml}$. sterile normal saline and, when the $18^{\circ}$ yeast flora was to be investigated, two fivefold dilutions were made from this. Inoculations were made on $100 \mathrm{~mm}$. plates of glucose Sabouraud agar which had been brought to $\mathrm{pH} 4$ immediately before dispensing. The soil suspensions were swilled over the medium, the excess moisture removed with a sterile pipette and the plates incubated upside down. Five plates/soil sample were inoculated with the heaviest suspension and incubated at $37^{\circ}$. In eight soils of which the $18^{\circ}$ yeast flora was investigated, a further five plates were inoculated and incubated at room temperature; one of these plates was inoculated with the heaviest suspension and two with each of the dilutions.

Plates held at $37^{\circ}$ were incubated for $2-3$ days before examination. With the exception of the cultures from one soil sample, all the yeast colonies which appeared were subcultured into glucose yeast extract broth and identified. In this exceptional case there were very many of one type of colony (subsequently found to be of Saccharomyces cerevisiae Hansen) and the yeasts from only one of the five plates inoculated were identified. Plates incubated at room temperature were kept for several days, the length of time being dependent upon the amount of mould growth which appeared, and twentyfour yeasts per soil sample were subcultured for identification. In each case they were picked systematically from a single plate or segment of a plate to avoid unconscious selection of large or otherwise conspicuous colonies.

Strains were identified by the keys and criteria of Lodder \& van Rij (1952). 
Melibiose broth for fermentation tests was prepared by the method of Skinner \& Bouthilet (1947).

Particular attention was paid to the 'starch'-producing ability of isolates, particularly those recovered in the investigation of the $18^{\circ}$ soil flora. Yeasts were subcultured upon the defined medium of Mager \& Aschner (1947), and after 1-2 weeks' incubation at room temperature were flooded with Lugol's iodine; the presence of starch was indicated by blue coloration. Ability to produce starch is the most important character which separates the genus Cryptococcus from the genus Torulopsis, being invariably present in the former and absent in the latter. Starch production also occurs sporadically throughout certain yeast genera other than Cryptococcus. It is present in certain species of Lipomyces, Bullera, Candida, Trichosporon and Rhodotorula (Aschner \& Cury, 1951; Lodder \& van Rij, 1952, pp. 31, 334 and 367), and is almost invariably associated with the presence of a capsule or less well organized extracellular slimes, although the reverse is not always true. Wickerham (1952) believes that starch synthesis may be an important key to the phylogenesis of yeasts and other closely related groups, but since this character is present in both the ascosporogenous Lipomyces and the ballistospore-producing Bullera, it can surely be of only minor use in tracing relationships.

\section{Problems of identification}

The majority of isolates were identified without trouble, but occasional difficulty was experienced. The strains of Torulopsis aeria (Saito) Lodder isolated varied from the description given by Lodder \& van Rij (1952, p. 413) in that the cells were oval rather than spherical. Connell \& Skinner (1953) placed this species in the genus Cryptococcus on the grounds that their isolates, and also the authentic strain obtained from Lodder, produced starch when tested by the method of Wickerham (1951). The former authors do not state how they separate their C. aerius from C. albidus (Saito) Skinner, which it resembles in cell shape, size and biochemical characters. None of the isolates described here as Torulopsis aeria synthesized starch.

Two strains isolated at $37^{\circ}$ and labelled Torulopsis famata (Harrison) Lodder \& van Rij were, it was felt, very smooth variants of Candida parapsilosis (Ashf.) Langeron \& Talice, but as no mycelium could be induced in them, they had to be placed in the former species. Both isolates fermented glucose more strongly than is usual for Torulopsis famata, and in addition one produced a bubble of gas in sucrose. The cell shape was oval rather than plump-oval to subglobose, and the cultures on solid media had the shiny yellowish appearance of Candida parapsilosis. Neither isolate synthesized starch, and so did not correspond to the Cryptococcus minor Poll. \& Nann. of Connell \& Skinner (1953). Difficulty was experienced in evoking mycelium in a number of other strains of Candida parapsilosis.

A new species of Cryptococcus (C. terreus) was isolated and a description of it has been published (di Menna, 1954a). 


\section{RESULTS}

Pathogenic yeasts

Three strains of Candida (Monilia) albicans were recovered from two soils. One strain, found in a soil sample from the Dunedin Botanical Gardens, was recognized by its fermentations and pathogenicity. Although it produced mycelium freely, no chlamydospores, which are diagnostic of the species and of the closely related $C$. stellatoidea (Jones \& Martin) Lang. \& Guerra, were seen upon repeated examination of cornmeal agar cultures. Miss A. v. d. Hoven v. Genderen of the Yeast Division, Centraalbureau voor Schimmelcultures, reported, however, that she was able to find chlamydospores in this strain on cornmeal agar slides after 4 days. Eighty million cells injected intravenously into a rabbit killed the animal in 2 days. The other two strains were recovered from a stockyard soil. They both produced chlamydospores within $24 \mathrm{hr}$. on cornmeal agar. Doses of 120 million and 80 million cells injected intravenously killed rabbits in 2 days.

Cryptococcus neoformans was not isolated. A strain of C. laurentii (Kuff.) Skinner which would grow at $37^{\circ}$ was recovered, and a second similar strain was found in an investigation of some soil not connected with this work. Both these yeasts were injected intraperitoneally into mice, but did not establish an infection. Yeasts could not be recovered from the peritoneal cavities of mice killed after the third post-injection day.

\section{Yeasts capable of growth at $37^{\circ}$}

A total of 162 strains were isolated from the 100 soil cultures incubated at $37^{\circ}$; of these eleven came from five of the thirty-eight urban soils, thirty-two from nine of the thirty-two rural soils, and 119 from twenty-six of the thirty stockyard soils. As the method used was not a quantitative one, counts are best made, not of the number of strains, but of the number of species isolated per sample.

Rhodotorula mucilaginosa (Jorg.) Harrison was the most common species; it was present in thirty-one soils. Candida parapsilosis was the next most frequently found, occurring in thirteen samples. Perfect yeasts were not very common. Saccharomyces cerevisiae, S. delbrueckii Lindner, and Pichia fermentans Lodder were each found in a single sample, and Debaryomyces subglobosus (Zach) Lodder \& van Rij and D. kloeckeri Guill. \& Peju were both present in two soils. Details of the numbers and sources of the heat-tolerant yeasts are given in Table 1.

The yeast flora which grew at room temperature $\left(\right.$ c. $\left.18^{\circ}\right)$

The $18^{\circ}$ yeast flora of seven of the eight soils examined showed a marked consistency of character. The typical yeast of this group was imperfect, colourless and capsulated, did not ferment sugars, utilized nitrate and produced starch on the appropriate medium. Of the 168 yeasts isolated from these seven soils 122 possessed all of the above characteristics, and 146 possessed at least four of them (see Table 2). The dominant yeast was Cryptococcus 
Table 1. Numbers of soil samples from which heat-tolerant yeasts were isolated

Figures in parentheses are the numbers of cultures isolated.

\begin{tabular}{|c|c|c|c|c|}
\hline & \multicolumn{4}{|c|}{ Type of soil } \\
\hline & $\begin{array}{l}\text { Urban } \\
\text { (38 samples) }\end{array}$ & $\begin{array}{c}\text { Rural } \\
\text { (32 samples) }\end{array}$ & $\begin{array}{l}\text { Stockyard } \\
\text { (30 samples) }\end{array}$ & $\begin{array}{c}\text { Total } \\
\text { (100 samples) }\end{array}$ \\
\hline $\begin{array}{l}\text { Saccharomyces cerevisiae } \\
\text { S. delbrueckii }\end{array}$ & $1(1)$ & . & $1(12)$ & $\begin{array}{l}1(12) \\
1(1)\end{array}$ \\
\hline Pichia fermentans & . & . & $1(1)$ & $1(1)$ \\
\hline $\begin{array}{l}\text { Debaryomyces kloeckeri } \\
\text { D. subglobosus }\end{array}$ & $\dot{.}$ & $1(1)$ & $\begin{array}{l}2(6) \\
1(1)\end{array}$ & $\begin{array}{l}2(6) \\
2(2)\end{array}$ \\
\hline $\begin{array}{l}\text { Torulopsis famata } \\
\text { T. candida (Saito) Lodder }\end{array}$ & $1(1)$ & $1(1)$ & $\begin{array}{c}2(2) \\
.\end{array}$ & $\begin{array}{l}3(3) \\
1(1)\end{array}$ \\
\hline $\begin{array}{l}\text { Candida albicans } \\
\text { C. macedonensis (Cast. \& } \\
\text { Chalmers) Berkh. } \\
\text { C. lipolytica (Harrison) } \\
\text { Diddens \& Lodder }\end{array}$ & $\begin{array}{l}1(1) \\
1(2) \\
.\end{array}$ & $1 \cdot$ & $\begin{array}{l}1(2) \\
1(1)\end{array}$ & $\begin{array}{l}2(3) \\
2(4) \\
1(1)\end{array}$ \\
\hline C. parapsilosis & $2(4)$ & $1(6)$ & $10(18)$ & $13(28)$ \\
\hline $\begin{array}{l}\text { Rhodotorula mucilaginosa } \\
\text { R. minuta (Saito) } \\
\text { Harrison }\end{array}$ & $1(2)$ & $6(19)$ & $\begin{array}{l}24(72) \\
1(1)\end{array}$ & $\begin{array}{l}31(93) \\
1(1)\end{array}$ \\
\hline $\begin{array}{l}\text { Trichosporon cutaneum } \\
\text { Failed to grow }\end{array}$ & . & $1 \dot{1(2)}$ & $\begin{array}{l}2(2) \\
1(1)\end{array}$ & $\begin{array}{l}2(2) \\
2(3)\end{array}$ \\
\hline Soils yielding yeasts & $5(11)$ & $9(32)$ & 26 (119) & $40(162)$ \\
\hline
\end{tabular}

Table 2. Some characteristics of species constituting the yeast flora of the soil which grew at room temperature $\left(\right.$ c. $\left.18^{\circ}\right)$

All organisms were colourless except the Rhodotorula glutinis.

\begin{tabular}{|c|c|c|c|c|}
\hline & $\begin{array}{l}\text { Utilizing } \\
\mathrm{KNO}_{3}\end{array}$ & $\begin{array}{l}\text { Producing } \\
\text { 'starch' }\end{array}$ & $\begin{array}{l}\text { Producing } \\
\text { capsules }\end{array}$ & $\begin{array}{l}\text { Fermentation } \\
\text { of sugars }\end{array}$ \\
\hline $\begin{array}{l}\text { Debaryomyces hansenii } \\
\text { D. kloeckeri } \\
\text { D. subglobosus } \\
\text { D. nicotianae }\end{array}$ & $\begin{array}{l}\overline{-} \\
\overline{-}\end{array}$ & $\begin{array}{l}- \\
- \\
- \\
-\end{array}$ & $\begin{array}{l}- \\
- \\
-\end{array}$ & $\begin{array}{l} \pm \\
\pm \\
\pm \\
\pm\end{array}$ \\
\hline $\begin{array}{l}\text { Cryptococcus laurentii } \\
\text { C. albidus } \\
\text { C. diffluens } \\
\text { C. terreus }\end{array}$ & $\begin{array}{l}- \\
+ \\
+ \\
+\end{array}$ & $\begin{array}{l}+ \\
+ \\
+ \\
+\end{array}$ & $\begin{array}{l}+ \\
+ \\
+ \\
+\end{array}$ & $\begin{array}{l}- \\
- \\
- \\
-\end{array}$ \\
\hline $\begin{array}{l}\text { Torulopsis aeria } \\
\text { T. famata }\end{array}$ & $\begin{array}{l}- \\
-\end{array}$ & $\begin{array}{l}- \\
-\end{array}$ & $\begin{array}{l}+ \\
-\end{array}$ & $\overline{-}$ \\
\hline $\begin{array}{l}\text { Candida tropicalis (Cast.) } \\
\text { Berkh. } \\
\text { C. humicola (Daszewska) }\end{array}$ & - & $\begin{array}{l}- \\
+\end{array}$ & $\begin{array}{l}- \\
+\end{array}$ & + \\
\hline $\begin{array}{l}\text { Diddens \& Lodler } \\
\text { C. brumptii }\end{array}$ & - & - & - & + \\
\hline $\begin{array}{l}\text { C. scottii Diddens \& } \\
\text { Lodder }\end{array}$ & + & - & - & - \\
\hline $\begin{array}{l}\text { Trichosporon pullulans } \\
\text { T. cutaneum }\end{array}$ & $\begin{array}{l}+ \\
-\end{array}$ & $\begin{array}{l}+ \\
+\end{array}$ & $\begin{array}{l}+ \\
+\end{array}$ & $\begin{array}{l}- \\
-\end{array}$ \\
\hline Rhodotorula glutinis & + & - & + & - \\
\hline
\end{tabular}


albidus (fifty-eight isolates), and the next most commonly occurring were C. terreus (forty-four isolates) and Trichosporon pullulans (Lindner) Diddens \& Lodder (twenty-six isolates).

The eighth soil (sample g), which was from peat at an altitude of $\mathbf{3 0 0 0} \mathrm{ft}$. with a $\mathrm{pH}$ value of \pm 4.5 , produced a pure culture of Candida brumptii Lang. \& Guerra, a fermenting uncapsulated species which does not assimilate nitrate, or produce a starch-like compound. Pseudomycelium was produced only slowly and in small quantities by all the strains isolated. It is considered likely that, promoted by the acidity of the soil (Langeron \& Guerra, 1939), these strains had varied a considerable distance in the $\mathbf{S}$ or non-mycelial direction, as had those strains of $C$. parapsilosis and presumptive $C$. parapsilosis mentioned in Methods.

Details of the yeasts isolated are given in Table 3. A greater variety of species was isolated from the tilled soils than from the untilled. The former yielded five to nine species per sample (a total of sixteen species from the group), and the latter one to three species (a total of six).

Table 3. Yeast flora which grew at c. $18^{\circ}$ from eight soil samples

\begin{tabular}{|c|c|c|c|c|c|c|c|c|c|}
\hline & \multicolumn{4}{|c|}{ Tilled soils } & \multicolumn{4}{|c|}{ Untilled soils } & \multirow[t]{2}{*}{ Tota } \\
\hline & $a$ & $b$ & $c$ & $d$ & $e$ & $f$ & $g$ & $\boldsymbol{h}$ & \\
\hline Debaryomyces hansenii & . & 2 & 1 & . & . & . & . & . & 3 \\
\hline D. kloeckeri & . & . & 3 & . & . & . & . & - & 3 \\
\hline D. subglobosus & . & 2 & 1 & . & . & . & . & . & 3 \\
\hline D. nicotianae & . & $\mathbf{2}$ & 1 & . & . & . & . & . & 3 \\
\hline Cryptococcus laurentii & 2 & . & . & . & 1 & 2 & . & . & 5 \\
\hline Cr. albidus & 8 & 4 & $\tilde{5}$ & . & 23 & 5 & . & 13 & 58 \\
\hline Cr. diffuens & . & . & . & 1 & . & . & . & . & 1 \\
\hline Cr. terreus & 4 & 14 & 1 & 1 & . & 17 & . & 7 & 44 \\
\hline Torulopsis aeria & 2 & . & . & . & . & . & . & . & $\mathbf{2}$ \\
\hline$T \cdot$ famata & - & . & 1 & . & . & . & . & . & 1 \\
\hline Candida tropicalis & . & . & . & 3 & . & . & . & . & 3 \\
\hline C. humicola & 2 & . & . & . & . & . & . & 4 & 6 \\
\hline C. brumptii & . & . & . & . & - & . & 24 & . & 24 \\
\hline C. scottii & 1 & . & . & . & . & . & . & . & 1 \\
\hline Trichosporon pullulans & 4 & . & 8 & 14 & . & . & . & . & 26 \\
\hline Tr. cutaneum & . & . & 3 & 5 & . & . & . & . & 8 \\
\hline Rhodotorula glutinis & 1 & . & - & . & . & . & . & . & $\mathbf{1}$ \\
\hline Total & 24 & 24 & 24 & 24 & 24 & 24 & 24 & 24 & 192 \\
\hline & & 500 & SIC & & & & & & \\
\hline & Pat & $g e$ & ic & & & & & & \\
\hline
\end{tabular}

It is believed that this is the first recorded occurrence of Candida albicans in the soil, and the second report of its being found unassociated with the mammalian or avian body. It is likely, however, that its apparent rarity away from these sites is not real, but due to lack of work upon the subject, for the preliminary experiments showed that it could at least survive in the soil for a considerable period. Its source in the soil is most likely to be the faeces of various wild and domestic animals in which it is a part of the normal gut flora. 
It has been recovered from the alimentary tracts of the European hedgehog and the Australian opossum which are common in both urban and rural areas in New Zealand (di Menna \& Parle, 1954), and it has also been isolated from the stomach contents of sheep and pigs (J. N. Parle, unpublished).

It had been hoped that Cryptococcus neoformans would be isolated in the course of this survey. Five infections with this organism have been diagnosed in New Zealand between 1948 and 1954. One of these was a lesion of the hand in a South Island man; the other four cases, in all of which the central nervous system was involved, came from a single area, $c .100$ miles in diameter, in the North Island. A search is still being made in soils from this area.

The isolation of $37^{\circ}$-tolerant strains of Cryptococcus laurentii during this work was of considerable interest in connexion with the pathogenicity of C. neoformans. Some earlier work upon the heat tolerance of Cryptococcus species had shown that in a group of forty-five strains of various species of this genus only $C$. neoformans could grow at a temperature of over $30^{\circ}$ (Table 4 ). This evidence suggested, as Mager \& Aschner (1947) noted, that ability to grow at the temperature of the mammalian body was the factor which conferred pathogenicity upon $C$. neoformans, and was reinforced by the fact that cryptococcosis can only rarely be induced in animals, such as the rabbit, whose body temperatures are at the threshold of the organisms' tolerance (Kuhn, 1939). The inability of strains of $C$. laurentii which grow freely at $37^{\circ}$ to produce an infection in mice when administered intraperitoneally suggests that it is not merely heat-tolerance and possession of a capsule which makes C. neoformans a pathogen.

Table 4. The effect of temperature upon growth of some yeast species

\begin{tabular}{|c|c|c|c|c|c|c|}
\hline & \multirow[b]{2}{*}{$\begin{array}{l}\text { Strains } \\
\text { tested } \\
\text { (no.) }\end{array}$} & \multicolumn{5}{|c|}{ Growth at } \\
\hline & & $20^{\circ}$ & $27^{\circ}$ & No. of strains & $33^{\circ}$ & $37^{\circ}$ \\
\hline Cryptococcus neoformans & 3 & $\mathbf{3}$ & $\mathbf{3}$ & $\mathbf{3}$ & 3 & 3 \\
\hline C. laurentii & 6 & 6 & $\mathbf{5}$ & 5 & $\mathbf{0}$ & 0 \\
\hline C. albidus & 9 & 9 & 7 & 6 & 0 & 0 \\
\hline C. diffluens & 27 & 27 & 25 & 20 & 0 & 0 \\
\hline Debaryomyces hansenii & 2 & 2 & nt & nt & nt & 0 \\
\hline D. kloeckeri & 18 & 18 & nt & nt & nt & 12 \\
\hline D. subglobosus & 4 & 4 & nt & nt & nt & 4 \\
\hline D. vini & 2 & 2 & nt & nt & nt & 1 \\
\hline D. nicotianae & $\mathbf{3}$ & $\mathbf{3}$ & nt & nt & nt & 1 \\
\hline D. marama & 13 & 13 & nt & nt & nt & 0 \\
\hline Torulopsis famata & 3 & 3 & nt & nt & nt & 2 \\
\hline Trichosporon cutaneum & 7 & 7 & 7 & nt & nt & 2 \\
\hline
\end{tabular}

$\mathrm{nt}=$ strains not tested at this temperature.

Yeasts capable of growth at $37^{\circ}$

With very minor exceptions, there is no resemblance between this group of yeasts and the yeast flora of the soil which grows at $c .18^{\circ}$. The finding that the numbers of heat-tolerant yeasts isolated was proportional to the amount 
of animal pollution suggested that the origin of most members of this group was the alimentary tract of domestic animals. Nevertheless, work in progress by J.N. Parle has so far only partially confirmed this. He has isolated Pichia fermentans and Trichosporon cutaneum (de Beurm., Gougerot \& Vaucher) Ota from the gut contents of sheep and pigs but has found Rhodotorula mucilaginosa and Candida parapsilosis, which were the most common heat-tolerant species, only very rarely in farm stock. In earlier work (di Menna, 1954b), both C. parapsilosis and Rhodotorula mucilaginosa were isolated from air, the latter in considerable numbers, but although this may explain the occurrence of these species in soil it does not explain why they should be concentrated in soil contaminated by animals.

There is considerable variation in the heat-tolerance shown by different strains of the same species. The effects of a range of temperatures upon the growth of a random selection of species of Debaryomyces and Cryptococcus (C. neoformans, C. laurentii, C. albidus, Cryptococcus diffluens (Zach) Lodder \& van Rij, Debaryomyces hansenii (Zopf) Lodder \& van Rij, D. kloeckeri, D. subglobosus, D. vini Zimmerman, Debaryomyces nicotianae Giovannozzi and Debaryomyces marama di Menna) and of Trichosporon cutaneum are shown in Table 4. This variation explains the apparent anomaly that whilst Debaryomyces species and Trichosporon cutaneum were isolated from soils cultured only at $37^{\circ}$ and from cultures of soils $(b),(c)$ and $(d)$ incubated at room temperature, they were not recovered from cultures of soils $(b),(c)$ and $(d)$ when they were incubated at $37^{\circ}$.

\section{Yeast flora growing at room temperature}

The results of this brief survey suggest that the soils of the Otago area, with the exception of peat soils, support a physiologically uniform yeast flora of non-fermenting capsulated colourless species which can synthesize a starch-like compound under certain conditions, and many of which can utilize nitrate nitrogen. The absence of the yeasts of the genus Lipomyces from these isolates was curious, for both Den Dooren de Jong in Holland (Lodder \& van Rij, 1952, p. 335) and Starkey (1946) in the United States isolated them repeatedly from soils. It is particularly interesting that the described species of Lipomyces possess most of the properties which are typical of the soil yeasts isolated here; they are colourless, capsulated, non-fermenting and synthesize starch, although weakly. It is possible that the polysaccharides of the capsules and slimes possessed by soil yeasts may be of some value in improving the physical properties of soil. Swaby (1949) reported that certain gum-producing bacteria were capable of binding together loose soil particles into water-stable aggregates. Yeasts, Swaby stated, did not improve aggregation, but he did not mention which yeasts he used. He found that the majority of bacterial slimes had no aggregating power because they remained water-soluble after drying.

No information appears to be available as to whether or not yeasts possess insoluble polysaccharides. However, it seems reasonable to suppose that a firmly outlined capsule, as is present in yeasts of the genus Cryptococcus in both solid and fluid cultures, must contain at least compounds which are 
poorly soluble in water. The capsular material found on species of other genera, in particular Rhodotorula glutinis (Fres.) Harrison, is less well organized and in Indian ink mounts may be seen streaming away from or even detached from the cell. This material can no longer be regarded as a true capsule, but is rather a cell-secreted mucus, and it seems likely that it may be of a watersoluble type. However, until more information is available it is useless to speculate upon this topic.

This work was carried out under a grant from the Medical Research Council of New Zealand.

The strain of Candida albicans isolated from urban soil and one of the strains isolated from stockyard soil have been deposited with the Centraalbureau voor Schimmelcultures (Yeast Division), Delft, Netherlands.

My thanks are due to Miss A. v. d. Hoven v. Genderen of the Centraalbureau voor Schimmelcultures (Yeast Division) for her assistance in the identification of some atypical strains of Cryptococcus terreus.

\section{REFERENCES}

Aschner, M. \& Cury, A. (1951). Starch production in the genus Trichosporon. J. Bact. 62, 350.

Connell, G. H. \& Skinner, C. E. (1953). The external surface of the human body as a habitat for non-fermenting non-pigmented yeasts. J. Bact. 66, 627 .

Emmons, C. W. (1951). Isolation of Cryptococcus neoformans from the soil. J. Bact. 62,685 .

Kunn, L. R. (1939). Growth and viability of Cryptococcus hominis at mouse and rabbit body temperatures. Proc. Soc. exp. Biol., N.Y. 41, 573.

LANGeron, M. \& Guerra, P. (1939). Valeur et nature des variations et dissociations des colonies chez des champignons levuriformes. Ann. Parasit. hum. comp. 17, 447 .

LODDER, J. \& van RiJ, N. J. W. (1952). The yeasts. Amsterdam: North-Holland Publishing Company.

MAger, J. \& Aschner, M. (1947). Biological studies on capsulated yeasts. J. Bact. $53,283$.

Marples, M. J. \& MenNa, M. E. DI (1952). The incidence of Candida albicans in Dunedin, New Zealand. J. Path. Bact. 64, 497.

Menna, M. E. Dr (1954a). Cryptococcus terreus n.sp., from soil in New Zealand. J. gen. Microbiol. 11, 195.

MeNNA, M. E. DI (1954,b). Non-pathogenic yeasts of the human skin and alimentary tract. J. Path. Bact. 68, 89.

Menna, M. E. Di \& Parle, J. N. (1954). Some extra-human occurrences of a pathogenic yeast. Proc. Univ. Otago med. Sch. 32, 2.

Negroni, P. \& Fischer, I. (1941). Contribucion al conocimiento de la flora micologica (microfitos) del delta del parana. Rev. Inst. bact. Malbrán, 10, 334.

Skinner, C. E. \& Bouthilet, R. (1947). Melibiose broth for classifying yeasts. J. Bact. 53, 37.

StaRkey, R. L. (1946). Lipid production by a soil yeast. J. Bact. 51, 33.

SwaBy, R. J. (1949). The relationship between micro-organisms and soil aggregation. J. gen. Microbiol. 3, 236.

Wickerham, L. J. (1951). 'Taxonomy of yeasts. Tech. Bull. U.S. Dep. Agric. no. 1029.

WiCkERHAM, L. J. (1952). Recent advances in the taxonomy of yeasts. Ann. Rev. Microbiol. 6, 317.

(Received 28 July 1954) 